\title{
ON THE ACCUMULATION OF ORGANIC MATTER ON THE SOUTHEASTERN BRAZILIAN CONTINENTAL SHELF: A CASE STUDY BASED ON A SEDIMENT CORE FROM THE SHELF OFF RIO DE JANEIRO
}

\author{
Renato da Silva Carreira ${ }^{l, *}$, Elizabeth A. Canuel, Stephen A. Macko ${ }^{3}$, Mariana B. Lopes ${ }^{4}$, \\ Letícia G. Luz and Luciana N. Jasmim ${ }^{4}$ \\ ${ }^{1}$ Pontificia Universidade Católica - Departamento de Química \\ (Rua Marquês de São Vicente, 225, 22453-900 Rio de Janeiro, RJ, Brasil) \\ ${ }^{2}$ College of William and Mary - School of Marine Science \\ (Gloucester Point, VA 23062, USA) \\ ${ }^{3}$ University of Virginia - Department of Environmental Sciences \\ (Charlottesville, VA 22903, USA) \\ ${ }^{4}$ Rio de Janeiro State University - School of Oceanography \\ (Rua São Franscisco Xavier, 524, 20550-013, Rio de Janeiro, RJ, Brasil) \\ *Corresponding author: carreira@puc-rio.br
}

\section{A B S TR ACT}

Sterol and fatty acid biomarkers and isotopic composition $(\delta 13 \mathrm{C}$ and $\delta 15 \mathrm{~N})$ of bulk organic matter $(\mathrm{OM})$ were quantified in a sediment core to characterize the accumulation of autochthonous OM in an area on the continental shelf adjacent to Rio de Janeiro State. In the sediment surface $(0-1 \mathrm{~cm})$ the concentration of total sterols and fatty acids was at least one order of magnitude higher than that measured deeper down in the core and was dominated by labile and planktonic-derived biomarker compounds. These results suggest, as is confirmed by multivariate statistical analysis, the occurrence of an event of enhanced primary production in the water column and efficient export of particles to the bottom. Similar conditions have been observed at Cabo Frio, located $150 \mathrm{~km}$ to the north of our study site, during an upwelling event, suggesting that such events may exert a regional influence on primary production on the south-eastern Brazilian continental shelf. Beyond the signatures from this event, the presence of biomarker compounds from vascular plants suggests the additional influence of an outflow from Guanabara Bay at the study site. These results point to the need for further investigation of the relative influence of physical forcings and continental inputs on the biogeochemical processes on the section of the continental shelf considered in the present study.

\section{RESUMO}

Marcadores moleculares na classe de lipídios (esterois, ácidos graxos e hidrocarbonetos) e a composição isotópica $(\delta 13 \mathrm{C}$ e $\delta 15 \mathrm{~N})$ da matéria orgânica bruta foram quantificados em amostras de um testemunho de sedimento para caracterizar o histórico recente de sedimentação da matéria orgânica na plataforma continental adjacente à Baía de Guanabara, no Estado do Rio de Janeiro. Na superfície do sedimento $(0-1 \mathrm{~cm})$, a concentração total de esterois e ácidos graxos foi cerca de uma ordem de grandeza maior do que observado nas camadas mais profundas do sedimento, com predominância de lipídios derivados da produção planctônica. Esses resultados sugerem, como confirmado através de estatística multi-variada, a ocorrência de um evento de elevada produção primária na coluna d’água e uma exportação rápida e eficiente das partículas para o sedimento. Condições similares são observadas na região de ressurgência de Cabo Frio, localizada cerca de 150 $\mathrm{km}$ ao norte da área de estudo. Portanto, nossos resultados sugerem que tais eventos têm uma influência regional sobre a produção primária na margem continental sudeste do Brasil. Por outro lado, a presença de lipídios derivados de plantas vasculares de origem continental ressalta a necessidade de investigar com maior profundidade a influência relativa entre forçantes físicas e o aporte continental sobre processos biogeoquímicos na porção da plataforma continental considerada no presente trabalho.

Descriptors: Lipid biomarker, Sediment core, Continental shelf, Rio de Janeiro, Guanabara Bay. Descritores: Lipídios biomarcadores, Testemunho de sedimento, Margem continental, Rio de Janeiro, Baía de Guanabara. 


\section{INTRODUCTION}

Continental shelves occupy only $7 \%$ of the total global ocean area but play a significant role in the global biogeochemical cycling of carbon (CAI et al., 2011; GATTUSO et al., 1998; VER et al., 1999). For instance, the high availability of nutrients derived from continental run-off, groundwater discharge and upwelling make continental shelves responsible for $14-30 \%$ of the total oceanic primary production and almost $90 \%$ of the fish catch (GATTUSO et al., 1998; FASHAM, 2003). In addition, mass balance calculations indicate that most continental margin regions are net autotrophic and thus may act as a sink for atmospheric $\mathrm{CO}_{2}$ (FRANKIGNOULLE; BORGES 2001; CHEN, 2004).

Although as much as $90 \%$ of the organic carbon accumulating in shelf sediments may be detrital (HEDGES; KEIL, 1995), uncertainties about the balance between import, production, recycling and export/accumulation of dissolved and particulate organic matter $(\mathrm{OM})$ in shelf sediments remain (HOPKINSON JR. et al., 2001). In particular, little is known about how these regions may respond to variability in physical, biological and chemical factors that drive ecosystem metabolism and to anthropogenic influences at the land-sea interface (MACKENZIE et al., 1993; GATTUSO et al. 1998; VER et al. 1999; BOYD; TRULL, 2007; GRIFFITH et al., 2009).

Characterization of the sources and distribution of $\mathrm{OM}$ in shelf sediments can be ascertained by lipid biomarker compounds (DUAN, 2000; JENG et al., 2003; YUNKER et al., 2005; TESI et al. 2007; MEAD; GOÑI, 2008; MEJANELLE; LAUREILLARD, 2008; WATERSON; CANUEL, 2008). Lipids have been widely used as tracers (or proxies) for identifying the origins of $\mathrm{OM}$ due to their source specificity and resistance to bacterial degradation relative to other classes of organic compounds (see review in VOLKMAN, 2006). By choosing either classes of lipids (e.g. sterols, fatty acids or hydrocarbons) or specific compounds that represent the different sources of $\mathrm{OM}$ and that are stable over time, it is possible to identify the relative contributions of autochthonous and allochthonous inputs to the sedimentary record over historical (CANUEL; MARTENS, 1993; DUAN, 2000; ZIMMERMAN; CANUEL, 2000; CARREIRA et al., 2002; WAKEHAM; CANUEL, 2006; VONK et al., 2008) or geological (MEYERS 1997; HINRICHS et al., 1999; XU et al., 2007) time-scales.

Information about the sources and fate of $\mathrm{OM}$ in recent sediments is limited for the southeastern Brazilian continental margin (SEBCM; 2300'$28^{\circ} 30^{\prime} \mathrm{S}$ ). Recent studies using isotopic and sedimentological information (MAHIQUES et al.,
2004; MAHIQUES et al., 2005) as well as lipid biomarker distributions (YOSHINAGA et al., 2008) suggest that $\mathrm{OM}$ accumulating in these sediments is mainly derived from autochthonous production, with a minor contribution from continental drainage. The low input of $\mathrm{OM}$ from continental sources is not surprising since there are no major rivers draining into this region and only small to medium estuaries are located nearby (EKAU; KNOPPERS, 1999). Instead, coastal and shelf-break upwelling events of cold and nutrient-rich South Atlantic Central Water (SACW), which are intense close to Cabo Frio $\left(23^{\circ} \mathrm{S}\right)$ during the springsummer months, have great influence over the pelagic and benthonic production in the region. These upwelling events may extend for over hundreds of $\mathrm{km}$ on the shelf (VALENTIN et al., 1987; LORENZZETTI; GAETA, 1996; CAMPOS et al., 2000; SILVEIRA et al., 2000) and have significant influence on the export and sedimentation of OM both over spatial and temporal scales (VALENTIN et al, 1986; GONZALEZ-RODRIGUEZ et al., 1992; SUMIDA et al., 2005; DE LEO; PIRES-VANIN 2006; MCMANUS et al., 2007; GUENTHER et al., 2008; YOSHINAGA et al., 2008). For instance, data for temperature and salinity of waters southwards from Cabo Frio suggested that meander-induced shelf break upwelling may have a significant role in the pumping of SACW from the slope region onto the continental shelf both in summer and winter months. This feature has also been observed by satellite images, where relatively enriched chlorophyll-a waters could be seen extending southward from Cabo Frio around the 100$\mathrm{m}$ isobaths, on the external platform region (e.g. ROSSI-WONGTSCHOWSKI; MADUREIRA, 2006). In addition, Yoshinaga et al. (2008) have observed that excursion of upwelling plumes, induced by meanders of the Brazil current, contribute to the transport of benthic larvae from Cabo Frio to southward-bound sub-tropical waters.

In this study, which can be considered preliminary because it is based on a limited set of samples, we used lipid biomarker compounds (sterols and fatty acids) and the isotopic composition $\left(\delta^{13} \mathrm{C}\right.$ and $\delta^{15} \mathrm{~N}$ ) of the bulk OM from a sediment core collected on the inner shelf of Rio de Janeiro state (Fig. 1) to: (i) characterize the local sedimentation of autochthonous $\mathrm{OM}$ in this region of SEBCM and compare it to that of the area of upwelling at Cabo Frio and (ii) evaluate the input of allochthonous materials (natural and anthropogenic) exported to the shelf by Guanabara Bay, a highly contaminated tropical estuary in the largest urban settlement in the Brazilian coastal zone (WAGENER, 1995; CARREIRA et al., 2004; NETO et al., 2006; DA SILVA et al,. 2007; FRANCIONI et al., 2007; SEIXAS et al., 2007; MACHADO et al., 2008). 


\section{Material and Methods}

Study Area and Sampling Procedures

The sampling site $\left(23^{\circ} 19^{\prime} 41^{\prime}, \mathrm{S}\right.$ and $43^{\circ} 11^{\prime} 51^{\prime \prime} \mathrm{W}$ ) was located $50 \mathrm{~km}$ to the south of Rio de Janeiro city, at a water column depth of $100 \mathrm{~m}$ (Fig. 1). This site was in the shelf area adjacent to Guanabara Bay with muddy sediments, and therefore had great potential to accumulate materials exported by the bay to the inner shelf along the Rio de Janeiro coast. Oligotrophic conditions predominate in the region due to the influence of waters from the Brazil Current (ROSSI-WONGTSCHOWSKI; MADUREIRA, 2006 and references therein), but may be influenced by the southward drifting of the upwelled plume of the cold and nutrient-rich South Atlantic Central Water (SACW) (VALENTIN, 1984; LORENZZETTI; GAETA 1996), whose core is at
Cabo Frio, approximately $120 \mathrm{~km}$ to the east of our sampling site. The coastal upwelling of Cabo Frio induces periods of enhanced primary production (2.0$\left.14.0 \mu \mathrm{gC} \mathrm{L}{ }^{-1} \mathrm{~h}^{-1}\right)($ GONZALEZ-RODRIGUEZ et al., 1992) in surface waters (<50 m depth) when northeasterly trade winds dominate in the springsummer months (September-March) (MOREIRA DA SILVA, 1973; VALENTIN; KEMPF 1977; FRANCHITO et al., 2008).

A sediment core $(\sim 0.5 \mathrm{~m}$ length) was collected in March 2002 (Fig. 1) using a gravity sampler (Kullenberg type) fitted with an aluminum internal liner. The core was kept in a vertical position during transport from the field. In the laboratory, the upper $25 \mathrm{~cm}$ of the core was sliced at $1 \mathrm{~cm}$ intervals and kept frozen $\left(-20^{\circ} \mathrm{C}\right)$ in pre-combusted $\left(450^{\circ} \mathrm{C}\right.$ overnight) aluminum containers. Before analysis, the sediments were thawed, dried at $60{ }^{\circ} \mathrm{C}$ and ground to a fine powder.

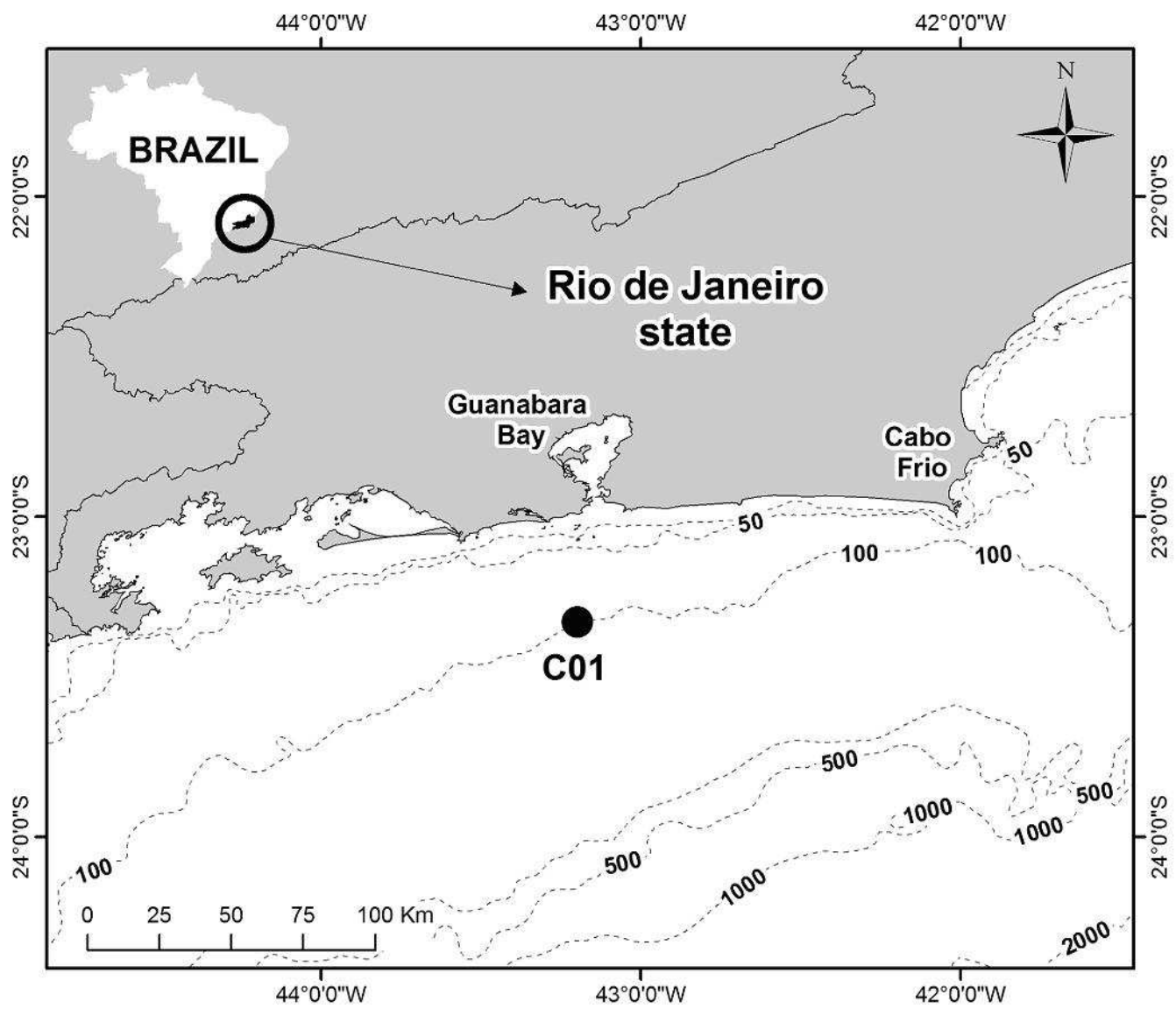

Fig. 1. Location where the core (C01) used for this study was collected in the inner shelf in the Rio de Janeiro state (SE Brazilian continental margin). Isobaths are represented by dashed lines. 
Bulk Organic Matter Analysis

Total organic carbon (TOC) and total nitrogen (TN) were determined using a Carlo Erba EA 1110 elemental analyzer after removal of inorganic carbon with 0.1 M HCl (HEDGES; STERN 1984). Sub-samples $(2-5 \mathrm{mg})$ were weighed (precision $= \pm$ $0.01 \mathrm{mg}$ ) into tin containers, folded and placed in the instrument. Quantification was performed by instrument response factor relative to the standard Cysteine. Analytical precision was greater than $3 \%$ for TOC and TN (based on 4 replicate analyses of the same sample) and accuracy was verified by analyzing a reference material (PACS-2, National Research Council of Canada). The data were corrected for carbonate content and thus expressed relative to bulk sediment.

For isotope analyses, carbonate was removed by acid treatment as described above and samples were oven dried to constant weight at $60{ }^{\circ} \mathrm{C}$. The carbonate-free residues were combusted to $\mathrm{CO}_{2}$ and $\mathrm{N}_{2}$ in an elemental analyzer (Carlo Erba EA), coupled to an OPTIMA stable isotope ratio mass spectrometer (Micromass, Manchester, UK). The stable isotopes are expressed as $\mathrm{d}^{N} \mathrm{E}=\left(R_{\text {sample }} / R_{\text {standard }}-1\right) \times 10^{3}$ (per mil or \%o), where $N$ is the heavy isotope of the element $\mathrm{E}$ and $R$ is the abundance ratio of the heavy to light isotopes of carbon and nitrogen $\left({ }^{13} \mathrm{C} /{ }^{12} \mathrm{C},{ }^{15} \mathrm{~N} /{ }^{14} \mathrm{~N}\right)$. The Pee Dee Belemnite limestone (PDB) and atmospheric $\mathrm{N}_{2}$ (air) were used as the standards for carbon and nitrogen, respectively.

\section{Lipid Biomarker Analysis}

Sediment samples (3.0 g, dry weight) were Soxhlet extracted with $210 \mathrm{~mL}$ of a mixture of dichloromethane and methanol (2:1, v:v) for $20 \mathrm{~h}$. Surrogate standards, including androstanol (5aandrostan-3b-ol $)$ and methylnonadecanoate $\left(\mathrm{C}_{19}\right.$-fatty acid methyl ester or $\mathrm{C}_{19}$-FAME). The total lipid extract was washed with a saturated solution of $\mathrm{NaCl}$ and the organic (dichloromethane) fraction was isolated. The aqueous phase was re-extracted using hexane and the organic phases combined. Following concentration by rotary evaporation, traces of water were removed by overnight treatment with anhydrous $\mathrm{Na}_{2} \mathrm{SO}_{4}$. A portion of the extract was saponified using $1 \mathrm{~mol} \mathrm{~L}{ }^{-1} \mathrm{KOH}$ in aqueous methanol $\left(110^{\circ} \mathrm{C}\right.$ for $\left.2 \mathrm{~h}\right)$. Neutral lipids (sterols) were extracted 3 times with $n$ hexane at $\mathrm{pH}>12$, followed by extraction of acidic lipids (fatty acids) into hexane after adjusting the $\mathrm{pH}$ to 2.0 with $3 \mathrm{~mol} \mathrm{~L}^{-1} \mathrm{HCl}$. Both neutral and acidic lipids were further purified by adsorption chromatography with silica-gel and/or alumina following published methods (CANUEL; MARTENS, 1993; CARREIRA et al., 2002). Before analysis, sterols were derivatized with bis-trimethylsilyl- trifluoroacetamide and fatty acids were methylated using $\mathrm{BF}_{3}$ in methanol. Analyses of fatty acids were performed using gas chromatography with flame ionization detection (Hewlett-Packard models 5890 series II and 6890) while sterols were analyzed by gas chromatography coupled to mass spectrometry (Finnigan Trace GC/PolarisQ GC/MS system). The GC/MS system was operated in the electron impact (EI; $70 \mathrm{eV}$ ) and full scan (50-550 amu) modes. A DB5 type column (5\% methyl-phenyl siloxane, $30 \mathrm{~m} \mathrm{x}$ $0.32 \mathrm{~mm} \times 0.25 \mu \mathrm{m}$ film) was used in both instruments. Quantification was based on the peak areas and the relative response to internal standards: $5 \alpha$-cholestane and $\mathrm{C}_{21}$-FAME for sterols and fatty acids, respectively. Laboratory blanks showed no contamination during sample processing. Recoveries of surrogates ranged between 40 and $60 \%$ for fatty acids and sterols. These recoveries were only used to assess analytical performance and no corrections were applied to the data.

Statistical Analyses

Principal component analysis was used to identify the dominant factors contributing to the variance in the data set (CANUEL, 2001; YUNKER et al., 2005). A total of 11 observations (sediment depth intervals) and 21 variables were selected, representing the most abundant sterols and fatty acids, as follows (see Tables 1 and 2 for abbreviations): (i) sterols: $27 \Delta^{5,22}, \quad 27 \Delta^{5}, 28 \Delta^{5,22}, 28 \Delta^{5,24(28)}, 28 \Delta^{5}, 29 \Delta^{5,22}$, $29 \Delta^{5}, 4 \alpha 30 \Delta^{22}$ and stanols (sum of $27 \Delta^{0}, 28 \Delta^{0}$, $29 \Delta^{0}, 28 \Delta^{22}$ ); (ii) fatty acids: branched (iso and anteiso $\mathrm{C}_{15}$ and $\mathrm{C}_{17}$ and 10-methyl- $\left.\mathrm{C}_{16}\right), \mathrm{C}_{16: 0}, \mathrm{C}_{16: 1}$, odd- $\mathrm{C}_{15^{-}}$ $\mathrm{C}_{17}, \mathrm{C}_{17: 1}, \mathrm{C}_{18: 1}, \mathrm{C}_{20: 1}, \mathrm{C}_{20}$ PUFA $\left(\mathrm{C}_{20: 4 \omega 6}, \mathrm{C}_{20: 5 \omega 3}\right), \mathrm{C}_{22: 0}$, $\mathrm{C}_{22: 5 \omega 3}, \mathrm{C}_{22: 6 \omega 3}$ and LCFA $\left(>\mathrm{C}_{23}\right.$, even and odd compounds). Prior to PCA analysis, the dry weight concentrations $\left(\mu \mathrm{g} \mathrm{g}^{-1}\right)$ were normalized by the centered $\log$ ratio method, which involves division of each variable by the summed concentration of all variables in a sample, followed by division by the geometric mean and log-transformation (YUNKER et al., 2005; WATERSON;CANUEL, 2008). Quartimax rotation was selected to represent the planar projection of the loadings (variables) and scores (samples) for the two principal components.

\section{RESUlts AND Discussion}

General Bulk Sediment Properties: TOC and Isotopic Composition of Organic Matter

Using sediment properties (grain size, organic carbon content and isotopic composition), the SEBCM was previously divided into two distinct sectors separated by a geographic boundary represented by São Sebastião island, on the coast of 
São Paulo state $\left(24^{\circ} \mathrm{S}-45^{\circ} \mathrm{W}\right)$ (MAHIQUES et al., 2004). Sedimentation in the northern region of the SEBCM was highly heterogeneous and characterized by patchy distribution of sediment properties. Generally, muddy sedimentary deposits in northern SEBCM were found at Cabo Frio and along the $100 \mathrm{~m}$ isobaths (MAHIQUES et al., 2004). Consistent with these observations, wet-sieving analyses showed that the core collected for this study (core C01), also collected at the $100 \mathrm{~m}$ isobath, was composed of mud throughout (Helio Vilhena-UERJ, personal communication). Despite the constant grain size, the total organic carbon (TOC) content in the $0-1 \mathrm{~cm}$ layer of core $\mathrm{C} 01$ (24.1 $\mathrm{mg} \mathrm{g}^{-1}$; Table 1) was more than three times higher than the mean TOC of $7.3 \pm 4.4 \mathrm{mg}$ $\mathrm{g}^{-1}$ observed in the northern SEBCM and even higher than typical values $\left(12-18 \mathrm{mg} \mathrm{g}^{-1}\right)$ measured in sediments from the Cabo Frio upwelling region (MAHIQUES et al., 2004; MAHIQUES et al., 2005). The mean TOC content of $11.4 \pm 1.8 \mathrm{mg} \mathrm{g}^{-1}$ for other depths in core C01 (Table 1) was similar to values observed regionally in the shelf (SOARES-GOMES et al., 1999; MAHIQUES et al., 2004), further emphasizing the elevated values for organic carbon content found in the $0-1 \mathrm{~cm}$ layer in the core analyzed for this study.

Table 1. Total organic carbon (TOC; $\left.\mathrm{mg} \mathrm{g}^{-1}\right), \delta^{13} \mathrm{C}$ and $\delta^{15} \mathrm{~N}(\% \mathrm{o})$ and sterols (in $\%$ of total concentration) in the sediment core on the continental shelf off Guanabara Bay, Rio de Janeiro.

\begin{tabular}{|c|c|c|c|c|c|c|c|c|c|c|c|c|c|c|c|c|c|c|c|c|c|}
\hline & \multicolumn{20}{|c|}{ Sediment layer $(\mathrm{cm})$} & \multirow[b]{2}{*}{$\begin{array}{l}24- \\
25\end{array}$} \\
\hline & $0-1$ & $1-2$ & $2-3$ & $4-5$ & 6-7 & $7-8$ & 8-9 & 9-10 & $\begin{array}{l}10- \\
11\end{array}$ & \begin{tabular}{|l}
$12-$ \\
13 \\
\end{tabular} & $\begin{array}{l}13- \\
14\end{array}$ & $\begin{array}{l}14- \\
15 \\
\end{array}$ & $\begin{array}{l}15- \\
16\end{array}$ & \begin{tabular}{|l}
$16-$ \\
17
\end{tabular} & $\begin{array}{l}17- \\
18 \\
\end{array}$ & $\begin{array}{l}18- \\
19 \\
\end{array}$ & $\begin{array}{l}20- \\
21\end{array}$ & $\begin{array}{l}21- \\
22\end{array}$ & $\begin{array}{l}22- \\
23\end{array}$ & \begin{tabular}{|l|}
$23-$ \\
24
\end{tabular} & \\
\hline TOC $\left(\mathrm{mg} \mathrm{g}^{-1}\right)$ & 24.5 & 12.1 & 13.5 & 14.5 & 15.1 & 11.8 & 11.9 & 11.0 & 11.2 & 11.1 & 11.0 & 9.0 & 13.3 & 9.7 & 8.9 & 10.7 & 9.9 & 8.9 & 9.5 & 10.7 & 11.1 \\
\hline$\delta^{13} \mathrm{C}(\%)$ & -24.1 & -25.5 & -24.1 & -22.9 & -23.8 & -23.0 & -24.3 & -24.7 & -22.3 & -21.2 & ${ }^{\mathrm{f}}$ na & na & na & na & na & na & na & na & na & na & na \\
\hline$\delta^{15} \mathrm{~N}(\%)$ & 9.0 & 9.4 & 8.7 & 7.2 & 9.7 & 9.0 & 8.2 & 9.8 & 8.1 & 7.5 & na & na & na & na & na & na & na & na & na & na & na \\
\hline \multicolumn{22}{|l|}{${ }^{a, b}$ Sterols (\%) } \\
\hline $26 \Delta^{5,22}$ & 1.1 & ${ }^{d} \operatorname{tr}$ & tr & $\operatorname{tr}$ & tr & tr & tr & tr & tr & tr & tr & tr & tr & tr & tr & $\operatorname{tr}$ & tr & - & tr & tr & tr \\
\hline $26 \Delta^{22}$ & tr & tr & $\mathrm{e}_{-}$ & tr & tr & tr & tr & tr & - & - & - & tr & tr & tr & tr & tr & tr & - & - & tr & tr \\
\hline nor $27 \Delta^{5,22}$ & 2.0 & 1.5 & tr & 1.4 & tr & tr & tr & tr & - & - & - & tr & tr & tr & tr & tr & tr & - & - & tr & tr \\
\hline $27 \Delta^{5,22}$ & 11.6 & 4.7 & 5.3 & 5.3 & 3.4 & 2.5 & 3.5 & 3.6 & 3.1 & 1.8 & tr & 1.4 & 1.9 & 2.6 & 2.0 & 2.5 & tr & 1.6 & 1.5 & 1.6 & 1.3 \\
\hline $27 \Delta^{5}$ & 42.4 & 11.8 & 9.6 & 12.5 & 10.5 & 9.4 & 11.5 & 12.4 & 11.3 & 23.5 & 8.8 & 8.8 & 13.2 & 9.3 & 7.8 & 11.0 & 4.8 & 5.0 & 6.7 & 7.9 & 7.5 \\
\hline $27 \Delta^{0}$ & 4.5 & 9.7 & 7.6 & 15.0 & 9.2 & 9.9 & 9.7 & 11.7 & 11.0 & 6.9 & 3.7 & 6.8 & 8.4 & 9.8 & 7.9 & 9.5 & 3.8 & 6.2 & 5.6 & 6.9 & 6.7 \\
\hline $28 \Delta^{5,22}$ & 10.0 & 11.3 & 6.6 & 12.2 & 8.0 & 6.3 & 7.1 & 8.3 & 7.0 & 3.7 & 1.7 & 3.7 & 4.3 & 5.8 & 4.4 & 6.2 & 2.7 & 3.7 & 3.5 & 3.6 & 3.2 \\
\hline $28 \Delta^{22}$ & tr & 4.2 & 2.9 & 4.8 & 3.6 & 2.8 & 3.9 & 4.8 & 3.5 & 2.9 & 1.8 & 4.0 & 2.9 & 3.3 & 2.3 & 3.2 & 1.7 & tr & 1.7 & 2.1 & 1.5 \\
\hline $28 \Delta^{5,24(28)}$ & 3.7 & 4.3 & 2.6 & 5.6 & 3.8 & 6.4 & 4.5 & 4.3 & - & 2.9 & - & 3.4 & 1.2 & 2.3 & 2.4 & 4.1 & 4.3 & 4.8 & 3.2 & 3.7 & 8.5 \\
\hline $28 \Delta^{5}$ & 9.4 & 12.1 & 9.5 & 5.7 & 11.4 & 14.3 & 10.0 & 10.2 & 13.8 & 9.0 & 8.2 & 10.9 & 8.8 & 9.1 & 11.5 & 3.9 & 5.4 & 10.7 & 12.9 & 10.3 & 13.0 \\
\hline $28 \Delta^{0}$ & - & - & - & - & - & - & 1.3 & 1.6 & 1.5 & - & - & 1.5 & 1.2 & tr & - & - & - & tr & tr & tr & tr \\
\hline $29 \Delta^{5,22}$ & $\operatorname{tr}$ & 9.2 & 5.9 & 9.8 & 8.0 & 6.7 & 6.7 & 8.3 & 7.8 & 6.9 & 4.1 & 10.8 & 6.3 & 7.6 & 7.4 & 9.0 & 4.7 & 5.7 & 5.4 & 6.1 & 6.1 \\
\hline $29 \Delta 5$ & 9.4 & 4.8 & 19.3 & - & 7.5 & 15.9 & 7.1 & 2.0 & 11.7 & 13.3 & 39.3 & - & 16.4 & 3.8 & 11.8 & 1.4 & 13.9 & - & 25.9 & 20.4 & 19.7 \\
\hline $29 \Delta^{0}$ & 2.9 & 12.4 & 16.1 & 1.4 & 13.7 & 10.6 & 15.1 & 13.7 & 12.9 & 18.3 & 25.1 & 27.6 & 20.1 & 26.8 & 23.8 & 25.7 & 52.3 & 47.6 & 24.6 & 27.8 & 23.0 \\
\hline $4 \alpha 30 \Delta^{22}$ & 1.6 & 13.0 & 13.3 & 25.1 & 19.0 & 13.7 & 17.8 & 16.9 & 15.9 & 10.5 & 6.5 & 19.3 & 14.3 & 18.1 & 17.7 & 21.8 & 4.6 & 13.0 & 8.5 & 8.1 & 7.9 \\
\hline $\begin{array}{l}\text { Total sterols } \\
\left(\mu \mathrm{g} \mathrm{g}^{-1}\right)\end{array}$ & 62.3 & 2.1 & 3.4 & 0.6 & 1.8 & 1.9 & 2.4 & 1.9 & 1.6 & 1.8 & 4.6 & 1.0 & 2.8 & 1.6 & 1.4 & 1.2 & 2.5 & 0.7 & 1.2 & 1.8 & 1.2 \\
\hline $\begin{array}{l}\text { Total sterols } \\
\left(\mathrm{mg} \mathrm{gTOC}^{-1}\right)\end{array}$ & 2.54 & 0.18 & 0.25 & 0.04 & 0.12 & 0.16 & 0.21 & 0.17 & 0.14 & 0.16 & 0.42 & 0.11 & 0.21 & 0.17 & 0.15 & 0.12 & 0.25 & 0.08 & 0.12 & 0.17 & 0.11 \\
\hline${ }^{\circ}$ Stanol/stenol & 0.12 & 0.77 & 0.62 & 0.90 & 0.78 & 0.52 & 0.91 & 1.10 & 0.69 & 0.55 & 0.51 & 1.83 & 0.77 & 1.66 & 1.02 & 2.17 & 2.33 & 3.49 & 0.67 & 0.91 & 0.76 \\
\hline
\end{tabular}

(a) all values of sterols in \% of individual compound to total sterols analyzed.

(b) symbol $\mathrm{a} \Delta^{\mathrm{b}, \mathrm{c}}(\mathrm{a}=$ number of $\mathrm{C}$ atoms; $\mathrm{b}, \mathrm{c}=$ position of the usaturation in the $\mathrm{C}$ structure) and stands for: 24-nor-cholesta-5,22E-dien-3 3 -ol

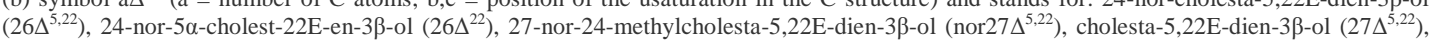

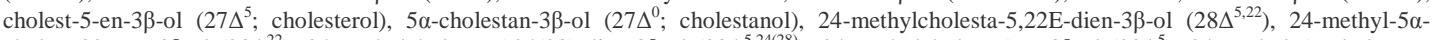

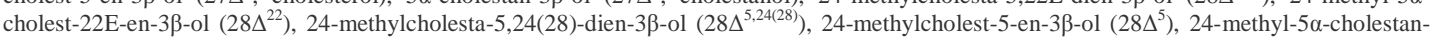

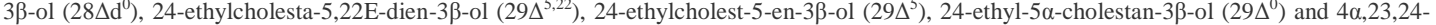
trimethyl-5 $\alpha$-cholest-22-en-3 $\beta$-ol $\left(4 \alpha 30 \Delta^{22}\right)$

(c) Stanol/stenol: $\left(27 \Delta^{0}, 28 \Delta^{0}, 29 \Delta^{0}\right) /\left(29 \Delta^{5}, 28 \Delta^{5}, 29 \Delta^{5}\right)$

(d) tr, denotes trace amounts $(<1 \%$ of total sterols $)$

(e) -, denotes below detection limits

(f) na $=$ not analysed

(g) bold face indicates sterol is amongst the six most abundant sterols (on a \% basis) comprising the total distribution 
Stable isotope values $\left(\delta^{13} \mathrm{C}\right.$ and $\left.\delta^{15} \mathrm{~N}\right)$ in the upper $13 \mathrm{~cm}$ ranged from -24.7 to -21.2 per mil (mean \pm s.d. $=-23.6 \pm 1.25$ ) and 7.2 to 9.7 per mil (mean \pm s.d. $=8.7 \pm 0.9$ ), respectively. $\delta^{3} \mathrm{C}$ values indicate a mixture of marine and terrigenous sources (e.g. MACKO et al., 1993; SCHMIDT et al., 2010). The $\delta^{15} \mathrm{~N}$ signatures ranged within the values commonly reported for marine $\mathrm{OM}$ on the shelf (e.g. MUZUKA; HILLAIRE-MARCEL, 1999). Overall, there was no trend in the changes in isotopic signatures with depths in the upper $13 \mathrm{~cm}$ suggesting that the sources of OM were constant over the timeframe represented by the core.
PCA Analyses

A total of $70.9 \%$ of the variance in the sterol and fatty acid data was explained by the two first components in the PCA analyses (Fig. 2). Compounds associated with heterotrophic bacteria (e.g. branched, odd $\mathrm{C}_{15}-\mathrm{C}_{17}$ ) and higher plants (i.e., long chain fatty acids; LCFA) (VOLKMAN, 2006), as well as compounds which tend to be more stable (e.g. saturated fatty acids such as 16:0, 18:0 and 22:0), had positive loadings on principal component 1 . In contrast, biomarkers derived from autochthonous production and of greater lability $\left(27 \Delta^{5}, 28 \Delta^{5,22}\right.$, $28 \Delta^{5,24(28)}$, PUFAs, etc.) (VOLKMAN, 2006) had negative loadings (Fig. 2-a).
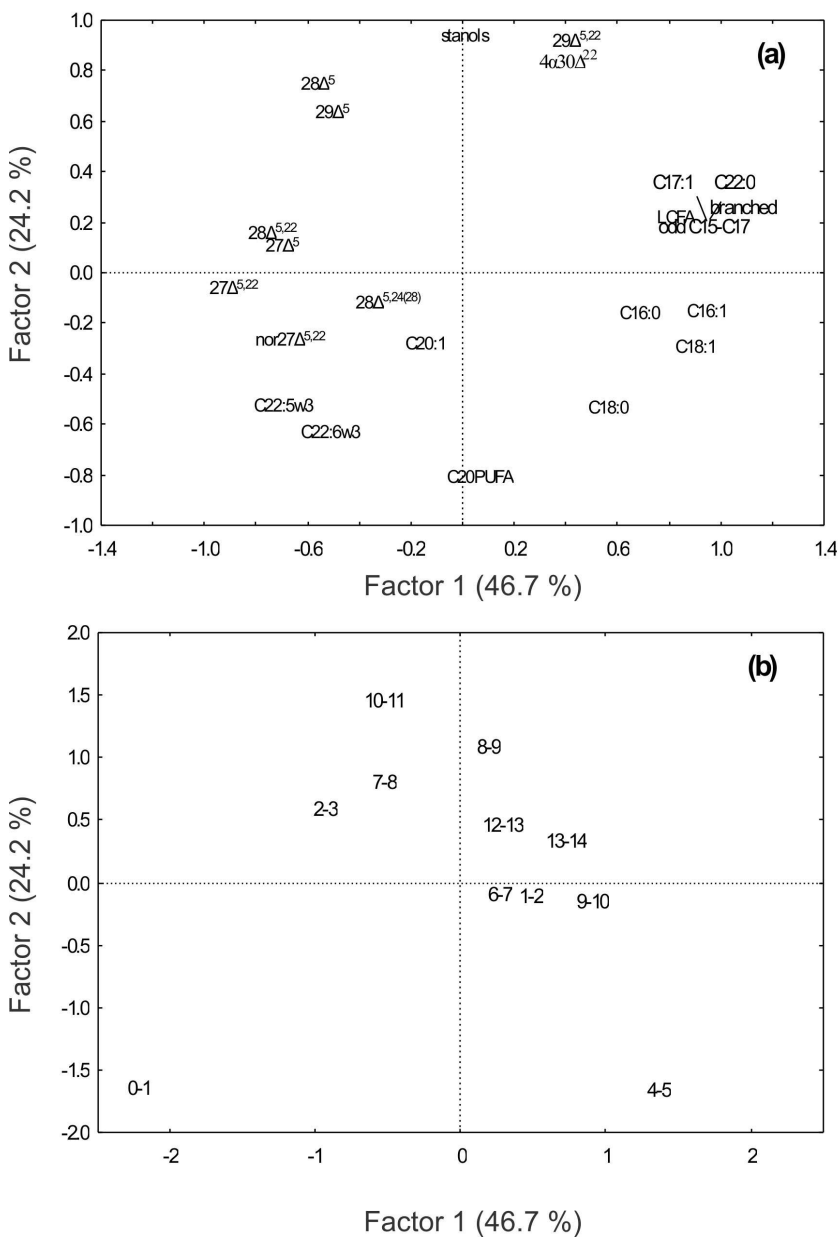

Fig. 2. Projections (quartimax rotated) of principal component 1 and principal component 2 obtained from the PCA analysis for lipids loadings (a) and sampling scores (b). Abbreviations used in the top panel (a) are provided in Tables 1 and 2 and values in the lower panel (b) represent the sediment core horizons (in $\mathrm{cm}$ ). 
Principal component 2 separated $\mathrm{C}_{28}-\mathrm{C}_{30}$ sterols and stanols (positive loadings) from mono- and polyunsaturated fatty acids (negative loadings) (Fig. 2a). Although the reactivity of lipids is highly variable and dependent on several factors (redox conditions, bioturbation, sedimentation rates, nature of organic matter, time after burial, among others) (WAKEHAM; CANUEL, 2006), apparent rate constants for lipids suggest the following sequence of susceptibility to decomposition: PUFA>MUFA>sterols (CANUEL; MARTENS, 1996; ARZAYUS; CANUEL 2005). Thus, principal component 2 likely differentiates between labile (negative loadings) and more refractory (positive loadings) compounds.

It is interesting to observe that principal component 2 grouped stanols, $4 \alpha 30 \Delta^{22}$ and the three sterols usually ascribed to terrestrial/riverine OM $\left(28 \Delta^{5}, 29 \Delta^{5,22}\right.$ and $\left.29 \Delta^{5}\right)$. These sterols did not group with other markers of phytoplankton production, such as $28 \Delta^{5,22}, 28 \Delta^{5,24(28)}$ or PUFAs, or with biomarkers for vascular plants, such as the long-chain fatty acids (LCFAs). One explanation for these groupings is that the sterols $28 \Delta^{5}, 29 \Delta^{5,22}$ and $29 \Delta^{5}$ may derive from both autochthonous and allochthonous sources of OM. Alternatively, the grouping of these compounds may reflect their resistance to bacterial decomposition due to their association with mineral phases (e.g., as soils or clay minerals) (KEIL;HEDGES, 1993).

The scores obtained in the PCA analyses isolated the $0-1 \mathrm{~cm}$ layer with very negative values for both principal components 1 and 2 (Fig. 2-b). This result is consistent with the unique composition of this sample including higher concentration of TOC and lipids, and biomarkers suggesting the presence of labile and recently deposited $\mathrm{OM}$ at the sediment surface. With increasing depth in the core, the scores (samples) were directed towards more positive values for principal components 1 and 2, reflecting preferential decomposition of labile compounds from autochthonous sources and selective preservation of bacterial and higher plant signatures.

\section{Sterols}

Overall, approximately fifteen sterols, comprising unsaturated and saturated $\mathrm{C}_{26}-\mathrm{C}_{30}$ compounds, were present in the 21 sediment layers $(0-$ $25 \mathrm{~cm}$ ) analyzed (Table 1). The concentration of total sterol at $0-1 \mathrm{~cm}$ was $62.3 \mu \mathrm{g} \mathrm{g}^{-1}$ (or $2.54 \mathrm{mg} \mathrm{gTOC}^{-1}$ ), while total sterol concentrations were one order of magnitude lower in the remaining horizons $(1.79 \pm$ $1.01 \mu \mathrm{g} \mathrm{g}^{-1}$ or $\left.0.16 \pm 0.09 \mathrm{mg} \mathrm{gTOC}^{-1}\right)$. Elevated concentrations of total sterols in the surface horizon of core $\mathrm{C} 01(0-1 \mathrm{~cm})$ and the steep gradient with depth are consistent with the delivery of fresh organic material (see above). It has been shown at Cabo Frio that the highest export of biogenic carbon occurs when the plankton community is dominated by opportunistic herbivorous copepod species, responsible for efficient grazing of the high phytoplankton biomass following an upwelling event (MCMANUS et al., 2007; GUENTHER et al., 2008). Short-term spatial and temporal variation in accumulation of sedimentary lipids has also been recorded in other upwelling regions, such as the Peruvian coast (WAKEHAM et al., 1984) and equatorial Pacific (WAKEHAM et al., 2002). Our results suggest a similar process, although additional information such as chlorophyll- $a$ concentrations and flux of biogenic particles in the water column is still necessary to confirm this hypothesis.

Total sterol concentrations in the $0-1 \mathrm{~cm}$ horizon $\left(62.3 \mu \mathrm{g} \mathrm{g}^{-1}\right.$ or $2.54 \mathrm{mg} \mathrm{gTOC}^{-1}$, Table 1$)$ were higher than the mean concentrations observed in surface sediments collected at $100 \mathrm{~m}$ depth in the nearby upwelling region of Cabo Frio (total sterols of $12.7 \pm 4.0 \mu \mathrm{g} \mathrm{g}^{-1}$ or $1.3 \pm 0.9 \mathrm{mg} \mathrm{gTOC}^{-1}$; YOSHINAGA et al., 2008). However, the mean total sterol concentration for the $1-5 \mathrm{~cm}$ sections was only $2.02 \pm 1.40 \mu \mathrm{g} \mathrm{g}^{-1}$ or $0.15 \pm 0.11 \mathrm{mg} \mathrm{gTOC}^{-1}$ (Table 1 ), which was in a range similar to that observed by Yoshinaga et al. (2008) at Cabo Frio (excluding the $100 \mathrm{~m}$ isobath). Sterol concentrations in core C01 were also lower than those observed in other shelf regions, such as the NE Atlantic (4.4 to $7.2 \mu \mathrm{g} \mathrm{g}^{-1}$; MEJANELLE; LAUREILLARD, 2008) and East China Sea (5.57 to $51.7 \mu \mathrm{g} \mathrm{g}^{-1}$; JENG; HUH 2001). These observations are consistent with the prevalent oligotrophic conditions typically observed in the SEBCM (ROSSI-WONGTSCHOWSKI; MADUREIRA, 2006) and provide additional evidence that the high concentration of sterols in the surface sediment was derived from a recent event, and does not represent the average deposition for the study area. Higher concentrations of sterols in the uppermost sediment suggest that sterols associated with previous depositional "events" have been rapidly degraded upon burial and/or are transported by bottom currents. Alternatively, the "event" captured in the surface sediments may be anomalous and not be reflective of typical conditions.

In the $0-1 \mathrm{~cm}$ horizon, sterol distributions were dominated by cholest-5-en-3 $\beta$-ol (cholesterol; $27 \Delta^{5}$ ), which comprised $42.4 \%$ of total sterols (Table 1). Cholesterol is produced by zooplankton during dietary alteration of phytosterols but it may also be found in some groups of algae (VOLKMAN, 1986; VOLKMAN et al., 1998). Other sterols in the $0-1 \mathrm{~cm}$ sediments include cholest-5,22-dien-3 $\beta$-ol $\left(27 \Delta^{5,22}\right)$ and 24-methylcholesta-5,22E-dien-3 $\beta$-ol $\left(28 \Delta^{5,22}\right)$, representing $11.6 \%$ and $10.0 \%$ of total sterols, respectively. The sterol $27 \Delta^{5,22}$ is not found in most species of unicellular algae (VOLKMAN et al., 1998; SCHEFUSS et al., 2004), but this compound may 
occur in diatoms (VOLKMAN, 1986). High concentrations of $27 \Delta^{5,22}$ have been associated with the fast sinking of organic matter via zooplankton faecal pellets (VOLKMAN, 2006). In contrast, $28 \Delta^{5,22}$ is abundant in diatoms but may also be produced by heterotrophic dinoflagellates (VOLKMAN, 1986). Yoshinaga et al. (2008) reported a similar distribution of sterols in sediments in the upwelling region of Cabo Frio, but these authors found increased abundances of 24-methylcholesta-5,24(28)-dien-3 $\beta$-ol $\left(28 \Delta^{5,24(28)}\right)$, a compound more specific to diatoms than $28 \Delta^{5,22}$, during summer/spring (VOLKMAN, 2006). In our samples, $28 \Delta^{5,22}$ represented less than $4.0 \%$ of total sterols in the $0-1 \mathrm{~cm}$ horizon (Table 1). Differences in the sterol composition of surface sediments between our study and the Yoshinaga et al. (2008) study suggest that plankton community structure in the SEBCM may change over short spatial and temporal time scales in response to the prevailing oceanographic conditions.

Although not abundant at the sediment surface $(0-1 \mathrm{~cm})$, the sterol $4 \alpha, 23,24-$ trimethyl-5 $\alpha$ cholest-22-en-3 $\beta$-ol $\left(4 \alpha 30 \Delta^{22}\right)$ represented one of the major compounds at greater depths in the core (14.3 \pm $5.4 \%$ of total sterols; Table 1). This sterol is associated mainly with dinoflagellate production (VOLKMAN, 2006) and, therefore, the relative enrichment observed in the deeper horizons of our sediment core suggests that these organisms may be important under "normal" conditions. This is consistent with the high abundance of this group of primary producers in the oligotrophic SEBCM waters, especially of the genus Ceratium (ROSSIWONGTSCHOWSKI; MADUREIRA, 2006).

In addition to a decrease in total sterol concentration with increasing depth in the core, there was a shift in sterol distribution (Table 1). In general, with increasing depth below $0-1 \mathrm{~cm}$ there was a trend towards higher contributions of $28 \Delta^{5}, 29 \Delta^{5,22}$ and $29 \Delta^{5}$ (Table 1). As suggested by the PCA analysis, these sterols may have mixed contributions from autochthonous and allochthonous sources of OM. The higher abundance of these sterols in deeper layers of the sediment core, together with the occurrence of $4 \alpha 30 \Delta^{22}$ (previously discussed), may result from the preferential preservation of these compounds (WAKEHAM; CANUEL, 2006). An increase in the stanol/stenol ratio from 0.12 at $0-1 \mathrm{~cm}$ to a mean of $1.15 \pm 0.77$ down in the core (Table 1 ) is consistent with the presence of 'fresh' OM at the sediment-water interface followed by bacterial alteration over time (NISHIMURA, 1982; WAKEHAM; CANUEL 2006).

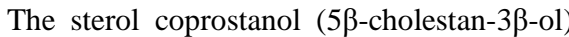
has been used to indicate the input of anthropogenic OM into SEBCM. However, coprostanol was below our analytical detection limits throughout the core. This may be due to both the distance from land-based sources of sewage (> 20 miles) and subsequent dilution of sewage particles as well as the higher degradation of coprostanol under oxic conditions in the water column in comparison to other compounds derived from continental runoff (MCCALLEY et al. 1981; SALIOT et al. 2002).

\section{Fatty Acids}

Fatty acids (FAs) were only analyzed from the surface down to $13 \mathrm{~cm}$ depth (Table 2). In general, the distribution of total FAs resembles that of sterols, although no significant correlation was found between the two classes of compounds. FAs had elevated concentrations in the sediment surface $\left(101.9 \mu \mathrm{g} \mathrm{g}^{-1}\right.$ or $4.2 \mathrm{mg} \mathrm{gTOC}^{-1}$, Table 2) and values one order of magnitude lower at greater depths $\left(10.0 \pm 4.7 \mu \mathrm{g} \mathrm{g}^{-1}\right.$ or $\left.0.81 \pm 0.41 \mathrm{mg} \mathrm{gTOC}^{-1}\right)$. Throughout the core, fatty acids were dominated by saturated compounds in the range $\mathrm{C}_{12}-\mathrm{C}_{30}\left(60-76 \%\right.$ of total FAs), with $\mathrm{C}_{16: 0}(19.9 \pm$ $4.8 \%)$ and $\mathrm{C}_{18: 0}(9.3 \pm 3.1 \%)$ representing the major compounds.

Individual fatty acids were grouped as indicative of $\mathrm{OM}$ derived from phytoplankton and zooplankton (sum of $\mathrm{C}_{18}, \mathrm{C}_{20}$ and $\mathrm{C}_{22}$ PUFAs), bacteria (sum of odd numbered $\mathrm{C}_{13}-\mathrm{C}_{17}$, linear and branched FA) and terrigenous sources/vascular plants (sum of even-numbered long-chain $\mathrm{FAs} \mathrm{C}_{24}-\mathrm{C}_{30}$ ) (MCCALLISTER et al, 2006). While FAs were dominated by compounds from phytoplankton and zooplankton in the $0-1 \mathrm{~cm}$ interval, contributions from these sources decreased downcore (Fig. 3). This is consistent with the downcore profile of sterols and provides additional evidence for the deposition of "fresh" organic matter at the sediment surface.

It is interesting to observe in Figure 3 the profile of the long-chain fatty acids (LCFAs), which are one of the most specific indicators of OM derived from vascular plants (VOLKMAN, 2006). The concentration of LCFAs in the $0-1 \mathrm{~cm}$ layer of our core $\left(0.47 \mathrm{mg}\right.$ gTOC $^{-1}$; Fig. 3$)$ was higher than the concentrations observed in surface sediment at the 100 $\mathrm{m}$ isobath at Cabo Frio (0.05 to $0.15 \mathrm{mg} \mathrm{gTOC}^{-1}$, YOSHINAGA et al., 2008), suggesting that there may be a higher contribution of $\mathrm{OM}$ from terrestrial/riverine sources at our site. The source of the LCFA at our sampling site is probably the outflow from Guanabara Bay, since there are no rivers in the region. In addition, the lack of correlation of LCFA and the sterols usually associated with vascular plants, i.e, $28 \Delta^{5}, 29 \Delta^{5,22}$ and $29 \Delta^{5}$ (VOLKMAN, 2006), indicates the need to consider fatty acids - or other classes of biomarkers, like lignin - to better constrain the delivery of continentally-derived $\mathrm{OM}$ to the SEBCM, instead of only using sterols. Moreover, LCFAs and bacterially-derived FAs were strongly correlated $\left(\mathrm{r}^{2}=0.91 ; p<0.01\right)$, which could be related 
to the presence of degraded $\mathrm{OM}$ in the sediment layers and/or may reflect selective preservation of these FAs relative to planktonic-derived FAs, like PUFAs (CANUEL; MARTENS, 1996; WAKEHAM;CANUEL, 2006).

Additionally, no monotonic decrease in fatty acids was observed downcore. Contributions from the three groups of FA varied with depth (e.g. minimum concentration at 6-7 $\mathrm{cm}$ and higher concentrations at $8-9 \mathrm{~cm}$ and $12-13 \mathrm{~cm}$; Fig. 3), which probably reflects changes in $\mathrm{OM}$ accumulation at the study site. Additional data from this and other regions of the SEBCM are necessary to investigate this point in greater detail.

Table 2. Fatty acid distribution in the sediment CO1 on the continental shelf off Guanabara Bay, Rio de Janeiro.

\begin{tabular}{|c|c|c|c|c|c|c|c|c|c|c|c|}
\hline \multirow[t]{2}{*}{ component (\%) } & \multicolumn{11}{|c|}{ Sediment layer $(\mathrm{cm})$} \\
\hline & $0-1$ & $1-2$ & $2-3$ & $3-4$ & $4-5$ & $6-7$ & $7-8$ & $8-9$ & $9-10$ & $10-11$ & $12-13$ \\
\hline $12: 0$ & $-a^{a}$ & - & $\operatorname{tr}^{\mathrm{b}}$ & $\operatorname{tr}$ & - & - & - & $\operatorname{tr}$ & - & $\operatorname{tr}$ & $\operatorname{tr}$ \\
\hline i13 & - & - & - & - & - & - & - & - & - & - & - \\
\hline a13 & - & - & - & - & - & - & - & - & - & - & - \\
\hline $13: 0$ & - & - & - & - & - & - & - & - & - & - & - \\
\hline 13:0 & - & - & - & - & - & - & - & - & - & - & - \\
\hline i14 & $\operatorname{tr}$ & $\operatorname{tr}$ & $\operatorname{tr}$ & $\operatorname{tr}$ & $\operatorname{tr}$ & $\operatorname{tr}$ & $\operatorname{tr}$ & $\operatorname{tr}$ & $\operatorname{tr}$ & - & $\operatorname{tr}$ \\
\hline $14: 1$ & $\operatorname{tr}$ & $\operatorname{tr}$ & - & $\operatorname{tr}$ & $\operatorname{tr}$ & $\operatorname{tr}$ & - & $\operatorname{tr}$ & - & - & $\operatorname{tr}$ \\
\hline $14: 0$ & 2.5 & 3.4 & 3.3 & 4.5 & 3.7 & 3.8 & 4.2 & 4.3 & 3.8 & 5.0 & 4.4 \\
\hline i15 & $\operatorname{tr}$ & 1.7 & 1.2 & 1.7 & 1.8 & 1.7 & 1.7 & 1.9 & 1.5 & 2.0 & 1.4 \\
\hline a15 & $\operatorname{tr}$ & 1.9 & 1.3 & 2.1 & 2.4 & 2.6 & 2.3 & 2.8 & 2.2 & 3.2 & 2.3 \\
\hline $15: 1$ & $\operatorname{tr}$ & - & - & $\operatorname{tr}$ & $\operatorname{tr}$ & $\operatorname{tr}$ & - & - & - & - & - \\
\hline $15: 0$ & 1.7 & 2.3 & 2.0 & 2.7 & 2.3 & 2.6 & 2.9 & 2.5 & 2.1 & 2.7 & 2.8 \\
\hline $16: 3$ & - & - & - & - & - & - & - & - & - & - & - \\
\hline $16: 2$ & - & - & - & - & - & - & - & - & - & - & - \\
\hline i16 & - & 1.7 & 1.3 & 1.6 & 1.5 & - & 1.5 & 1.5 & 1.2 & 1.7 & $\operatorname{tr}$ \\
\hline $16: 1 \omega 9$ & 3.1 & - & - & 5.6 & - & 2.8 & 2.6 & 3.9 & 1.5 & 4.0 & 6.7 \\
\hline $16: 1 \omega 7$ & 1.8 & 6.4 & 3.6 & 5.4 & 7.3 & 6.4 & 4.9 & 5.0 & 3.7 & 3.7 & $\operatorname{tr}$ \\
\hline $16: 0$ & $21.1^{\mathrm{c}}$ & 19.4 & 17.7 & 21.7 & 19.7 & 24.5 & 23.1 & 21.2 & 21.1 & 6.6 & 22.7 \\
\hline 10 methyl- $\mathrm{C}_{16}$ & $\operatorname{tr}$ & 1.8 & $\operatorname{tr}$ & 1.2 & 1.8 & 1.9 & 1.4 & 1.7 & 1.2 & 1.6 & 1.4 \\
\hline i17 & $\operatorname{tr}$ & $\operatorname{tr}$ & $\operatorname{tr}$ & $\operatorname{tr}$ & $\operatorname{tr}$ & $\operatorname{tr}$ & $\operatorname{tr}$ & $\operatorname{tr}$ & $\operatorname{tr}$ & $\operatorname{tr}$ & $\operatorname{tr}$ \\
\hline a17 & $\operatorname{tr}$ & $\operatorname{tr}$ & $\operatorname{tr}$ & $\operatorname{tr}$ & $\operatorname{tr}$ & $\operatorname{tr}$ & $\operatorname{tr}$ & $\operatorname{tr}$ & $\operatorname{tr}$ & $\operatorname{tr}$ & 1.2 \\
\hline $17: 1$ & $\operatorname{tr}$ & $\operatorname{tr}$ & $\operatorname{tr}$ & 1.0 & $\operatorname{tr}$ & $\operatorname{tr}$ & $\operatorname{tr}$ & $\operatorname{tr}$ & $\operatorname{tr}$ & $\operatorname{tr}$ & $\operatorname{tr}$ \\
\hline $17: 0$ & 1.6 & 1.9 & 1.9 & $\operatorname{tr}$ & 1.9 & 2.2 & 1.9 & 1.6 & 1.8 & 1.9 & 1.7 \\
\hline $18: 4$ & - & - & - & - & - & - & - & - & - & - & - \\
\hline $18: 3$ & $\operatorname{tr}$ & - & - & $\operatorname{tr}$ & - & - & - & - & - & $\operatorname{tr}$ & - \\
\hline $18: 2$ & 1.7 & $\operatorname{tr}$ & 1.0 & 1.7 & 1.1 & 2.0 & 1.3 & 1.1 & 1.0 & 1.3 & 1.2 \\
\hline $18: 1 \omega 9 \mathrm{c}$ & 8.5 & 6.0 & 4.5 & 6.8 & 5.8 & 7.5 & 6.2 & 6.0 & 4.7 & 7.0 & 6.0 \\
\hline $18: 1 \omega 9 t$ & 2.9 & 6.3 & 4.3 & 4.8 & 6.4 & 5.3 & 4.8 & 4.2 & 3.2 & 4.0 & 2.9 \\
\hline $18: 0$ & 18.1 & 8.1 & 8.0 & 8.1 & 7.3 & 10.9 & 8.4 & 7.5 & 8.1 & 9.6 & 8.7 \\
\hline $20: 4 \omega 6$ & 2.5 & 1.6 & $\operatorname{tr}$ & $\operatorname{tr}$ & $\operatorname{tr}$ & $\operatorname{tr}$ & - & $\operatorname{tr}$ & - & $\operatorname{tr}$ & $\operatorname{tr}$ \\
\hline $20: 5 \omega 3$ & 5.1 & 1.3 & $\operatorname{tr}$ & $\operatorname{tr}$ & $\operatorname{tr}$ & $\operatorname{tr}$ & - & $\operatorname{tr}$ & - & $\operatorname{tr}$ & $\operatorname{tr}$ \\
\hline $20: 3$ & $\operatorname{tr}$ & $\operatorname{tr}$ & $\operatorname{tr}$ & $\mathrm{tr}$ & $\operatorname{tr}$ & $\mathrm{tr}$ & - & $\operatorname{tr}$ & - & - & $\operatorname{tr}$ \\
\hline $20: 2$ & $\operatorname{tr}$ & $\operatorname{tr}$ & $\operatorname{tr}$ & $\operatorname{tr}$ & $\operatorname{tr}$ & - & - & $\operatorname{tr}$ & - & - & $\operatorname{tr}$ \\
\hline $20: 1$ & 2.0 & 1.8 & 9.6 & $\operatorname{tr}$ & 1.0 & 2.8 & - & $\operatorname{tr}$ & - & - & 1.3 \\
\hline $22: 6 \omega 3$ & 4.3 & - & $\operatorname{tr}$ & $\mathrm{tr}$ & $\operatorname{tr}$ & - & - & - & - & - & - \\
\hline $22: 5 \omega 3$ & 2.8 & - & $\operatorname{tr}$ & $\operatorname{tr}$ & $\operatorname{tr}$ & - & - & - & - & - & - \\
\hline $22: 2$ & - & - & $\mathrm{tr}$ & $\operatorname{tr}$ & $\operatorname{tr}$ & - & - & - & - & - & - \\
\hline $22: 1 \omega 9$ & - & - & $\operatorname{tr}$ & $\operatorname{tr}$ & $\operatorname{tr}$ & - & - & - & - & - & - \\
\hline 22:0 & 2.1 & 3.9 & 4.4 & 3.2 & 3.9 & 3.2 & 4.0 & 3.1 & 4.6 & 2.3 & 3.8 \\
\hline 23:0 & 1.5 & 2.7 & 3.0 & 2.0 & 2.6 & 1.9 & 2.8 & 1.8 & 3.4 & 2.9 & 2.7 \\
\hline $24: 1$ & - & - & - & - & - & - & - & - & - & - & - \\
\hline 24:0 & 4.2 & 7.5 & 7.9 & 6.0 & 7.6 & 4.5 & 7.6 & 6.2 & 9.2 & 9.3 & 7.7 \\
\hline 25:0 & 1.0 & 1.7 & 1.8 & 1.4 & 1.7 & $\operatorname{tr}$ & 1.8 & 1.4 & 2.2 & 2.2 & 1.8 \\
\hline 26:0 & 4.7 & 7.6 & 8.5 & 5.8 & 7.5 & 3.6 & 7.6 & 6.7 & 10.6 & 10.7 & 8.0 \\
\hline 27:0 & $\operatorname{tr}$ & $\operatorname{tr}$ & $\operatorname{tr}$ & $\operatorname{tr}$ & $\operatorname{tr}$ & $\operatorname{tr}$ & $\operatorname{tr}$ & $\operatorname{tr}$ & $\operatorname{tr}$ & 1.1 & $\operatorname{tr}$ \\
\hline 28:0 & 1.9 & 3.4 & 4.2 & 2.7 & 3.3 & 1.8 & 3.1 & 4.2 & 5.6 & 6.6 & 3.4 \\
\hline 29:0 & $\operatorname{tr}$ & $\operatorname{tr}$ & $\operatorname{tr}$ & $\operatorname{tr}$ & $\operatorname{tr}$ & $\operatorname{tr}$ & $\operatorname{tr}$ & $\operatorname{tr}$ & $\operatorname{tr}$ & 1.3 & $\operatorname{tr}$ \\
\hline $30: 0$ & $\operatorname{tr}$ & 1.7 & 2.5 & 1.4 & 1.7 & 1.1 & 1.6 & 3.3 & 3.3 & 5.1 & 1.7 \\
\hline Total FA $\left(\mu \mathrm{g} \mathrm{g}^{-1}\right)$ & 101.9 & 15.3 & 8.6 & 12.2 & 11.0 & 4.1 & 8.4 & 16.5 & 3.0 & 6.5 & 14.6 \\
\hline Total FA (mg gTOC $\left.{ }^{-1}\right)$ & 4.2 & 1.3 & 0.6 & 0.9 & 0.8 & 0.3 & 0.7 & 1.4 & 0.3 & 0.6 & 1.3 \\
\hline
\end{tabular}

a -, denotes below detection limits

${ }^{\mathrm{b}}$ tr, denotes trace amounts $(<1 \%$ of total FA)

${ }^{\mathrm{c}}$ boldface indicates FA is amongst the six most abundant FA (on a \% basis) comprising the total distribution 


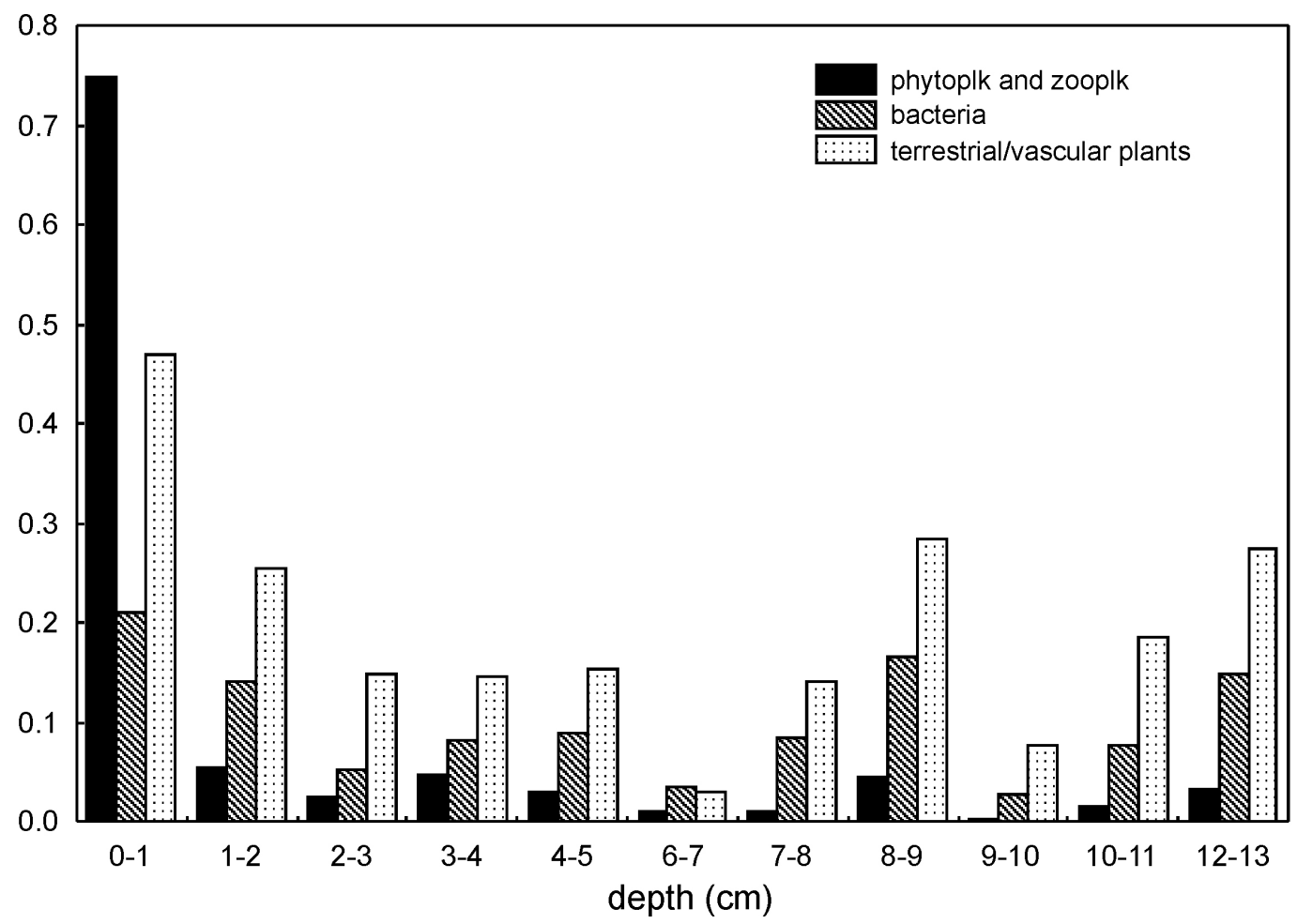

Fig. 3. Distribution of fatty acids (FA, in $\mathrm{mg} \mathrm{g}^{-1} \mathrm{TOC}$ ) in the core C01, grouped accordingly to McCallister et al., 2006, as (i) phytoplankton and zooplankton: sum of $\mathrm{C}_{18}, \mathrm{C}_{20}$ and $\mathrm{C}_{22}$ PUFA; (ii) bacteria: sum of odd numbered $\mathrm{C}_{13}-\mathrm{C}_{17}$, linear and branched $\mathrm{FA}$; and (iii) terrigenous/vascular plant: sum of even long chain FA $\mathrm{C}_{24}-\mathrm{C}_{30}$.

\section{Conclusions}

Findings from this study revealed that the influence of SACW upwelling on the production and export of OM to sediments is not restricted to the Cabo Frio region but extends regionally to the shelf. In addition, the presence of lipids derived from vascular plants suggested that the outflow from Guanabara Bay influences accumulation of OM on the shelf; this must, however, be better investigated. Our results demonstrate the benefits of utilizing multiple classes of biomarkers and the need for studying organic matter composition with greater spatial and temporal coverage on the shelf due to the complex dynamics associated with this region. A regional program where suspended particles and sediment samples are collected regularly would provide valuable insights into the processes controlling the biogeochemical cycling of OM on the Rio de Janeiro continental shelf.

\section{ACKNOWLEDGEMENTS}

This work was funded by FAPERJ (Fundação de Amparo à Pesquisa do Estado do Rio de Janeiro, grant n. E-26/150.332/2002). M. B. Lopes, L. G. Luz and L. N. Jasmim were supported by grants from PIBIC-UERJ (Programa de Bolsas de Iniciação Científica da Universidade do Estado do Rio de Janeiro). The authors are grateful to Dr. Angela Wagener, Dr. Arthur Scofield and Dr. Claudia Hamacher for their assistance with GC/MS analysis. This paper is contribution 3198 of the Virginia Institute of Marine Science, College of William and Mary.

\section{REFERENCE}

ARZAYUS, K. M.; CANUEL, E. Organic matter degradation in sediments of the York River estuary: Effects of biological vs. physical mixing. Geochim. cosmochim. Acta, v. 69, p. 455-464, 2005. 
BOYD, P. W.; TRULL, T. W. Understanding the export of biogenic particles in oceanic waters: Is there consensus? Progr. Oceanog., v. 72, p. 276-312, 2007.

CAI, W-J. Estuarine and coastal ocean carbon paradox: $\mathrm{CO}_{2}$ sinks or sites of terrestrial carbon incineration? Annu. Rev. mar. Sci., v. 3, p. 123-45, 2011 doi:10.1146/annurev-marine-120709-142723

CAMPOS, E. J. D; VELHOTE, D.; SILVEIRA, I. C. A. Shelf break upwelling driven by Brazil Current cyclonic meanders. Gephys. Res. Lett., v. 27, p. 751-754, 2000.

CANUEL, E. A. Relations between river flow, primary production and fatty acid composition of particulate organic matter in San Francisco and Chesapeake Bays: a multivariate approach. Org. Geochem v. 32, p. 563583,2001

CANUEL E. A.; MARTENS, C. S. Seasonal variations in the sources and alteration of organic matter associated with recently-deposited sediments. Org. Geochem., v. 20, p. 563-577, 1993.

CANUEL E. A.; MARTENS, C. S. Reactivity of recently deposited organic matter: degradation of lipid compounds near the sediment-water interface. Geochim. cosmochim. Acta, v. 60, p. 1793-1806, 1996.

CARREIRA, R. S; WAGENER, A. L. R.; FILEMAN, T; READMAN, J; MACKO, S. A. ; VEIGA, A. Changes in sedimentary organic carbon pool of a fertilized tropical estuary, Guanabara Bay, Brazil: an elemental, isotopic and molecular marker approach. Mar. Chem., v. 79, p. 207-227, 2002.

CARREIRA, R. S.; WAGENER, A. L. R.; READMAN, J. W. Sterols as markers of sewage contamination in a tropical urban estuary (Guanabara Bay, Brazil): spacetime variations. Estuar. coast. Shelf Sci., v. 60, p. $587-$ 598, 2004.

CHEN, C-TA. Exchanges of carbon in the coastal oceans. In: FIELD, C.B.; RAUPACH, M.R .(Ed.). SCOPE 62 The Global Carbon Cycle: Integrating humans, climate, and the natural world. Washington/DC: Island Press, 2004. p. 341-351.

DA SILVA, T. F.; AZEVEDO, D. D. A.; NETO, F. R. D. A. Distribution of polycyclic aromatic hydrocarbons in surface sediments and waters from Guanabara Bay, Rio de Janeiro, Brazil. J. Braz. Chem. Soc., v. 18, p. 628637, 2007.

DE LEO, F. C.; PIRES-VANIN, A.M.S. Benthic megafauna communities under the influence of the South Atlantic Central Water intrusion onto the Brazilian SE shelf: A comparison between an upwelling and a non-upwelling ecosystem. J. mar. Syst., v. 60, p. 268-284, 2006.

DUAN, Y. Organic geochemistry of recent marine sediments from the Nansha Sea, China. Org. Geochem., v. 31, p.159-167, 2000.

EKAU, W.; KNOPPERS, B. A. An introduction to the pelagic system of the North-East and East Brazilian shelf. Arch. Fish. mar Res., v. 47, p. 113-132,1999.

FASHAM, M.J.R. Ocean biogeochemistry: the role of the ocean carbon cycle in global change. Berlin: Springer Verlag, 2003. 297 p.

FRANCHITO, S. H.; ODA, T. O.; RAO, V. B.; KAYANO, M. T. Interaction between coastal upwelling and local winds at Cabo Frio, Brazil: an observational study. J. appl. Meteorol. Climatol., v. 47, p. 1590-1598, 2008.

FRANCIONI, E.; WAGENER, A. L. R.; SCOFIELD, A. L.; DEPLEDGE, M. H.; CAVALIER, B.; SETTE, C. B.;
CARVALHOSA, L.; LOZINSKY, C.; MARIATH, R. Polycyclic aromatic hydrocarbon in inter-tidal mussel Perna perna: Space-time observations, source investigation and genotoxicity. Sci. total Environment, v. 372, p. 515-531, 2007.

FRANKIGNOULLE, M.; BORGES A. V. European continental shelf as a significant sink for atmospheric carbon dioxide. Global biogeochem.Cycles, v. 15, p. 569-576, 2001

GATTUSO J-P.; FRANKIGNOULLE, M.; WOLLAST R. Carbon and carbonate metabolism in coastal aquatic ecosystems. Annu. Revs ecol. Systems, v. 29, p. 405434

GONZALEZ-RODRIGUEZ, E.; VALENTIN， J. L; ANDRÉ, D. L.; JACOB, S. A. Upwelling and downwelling at Cabo Frio (Brazil): comparison of biomass and primary production responses. J. Plankt. Res., v. 14, p. 289-306, 1992.

GRIFFITH, D. R.; BARNES, R. T.; RAYMOND, P. A. Inputs of fossil carbon from wastewater treatment plants to U.S. rivers and oceans. Environ. Sci. Technol., v. 43, p. 5647-5651, 2009.

GUENTHER, M.; GONZALEZ-RODRIGUEZ, E.; CARVALHO, W.F.; REZENDE C.E.; MUGRABE, G.; VALENTIN, J.L. Plankton trophic structure and particulate organic carbon production during a coastal downwelling-upwelling cycle. Mar. Ecol. Prog. Ser., .v. 363, p. 109-119, 2008.

GUENTHER, M.; PARANHOS, R.; REZENDE, C. E.; GONZALEZ-RODRIGUES, E.; VALENTIN, J. L. Dynamics of bacterial carbon metabolism at the entrance of a tropical eutrophic bay influenced by tidal oscillation. Aquat. Microb. Ecol ., v. 50, p. 123-133, 2008.

HEDGES, J.I.; KEIL, R.G. Sedimentary organic matter preservation: an assessment and speculative synthesis. Mar. Chem., v. 49, p. 81-115, 1995.

HEDGES, J. I.; STERN J. H. Carbon and nitrogen determinations of carbonate-containing solids. Limnol. Oceanogr., v. 29, p. 657-663, 1984.

HINRICHS, K. U.; SCHNEIDER, R. R.; MULLER, P. J.; RULLKOTTER, J. A biomarker perspective on paleoproductivity variations in two Late Quaternary sediment sections from the Southeast Atlantic Ocean. Org. Geochem., v. 30, p. 341-366, 1999.

HOPKINSON JR., C.S.; GIBLI, A.E.; TUCKER, J. Benthic metabolism and nutrient regeneration on the continental shelf of Eastern Massachusetts, USA. Mar.Ecol. Prog. Ser ., v. 224, p. 1-19, 2001.

JENG, W-L; HUH C-A. Comparative study of sterols in shelf and slope sediments off northeastern Taiwan. Appl. Geochem., v. 16, p. 95-108, 2001.

JENG, W-L.; LIN, S.; KAO, S-J. Distribution of terrigenous lipids in marine sediments off northeastern Taiwan. Deep Sea Res., II, Top Stud Oceanogr., v. 50, p. 11791201, 2003.

KEIL, R. G.; HEDGES, J. I. Sorption of organic matter to mineral surfaces and the preservation of organic matter in coastal marine sediments. Chem. Geol., v. 107, p. 385-388, 1993.

LORENZZETTI, J. A. GAETA, S. A. The Cape Frio upwelling effect over the South Brazil Bight northern sector shelf waters: a study using AVHRR images. International Archs Photogram. Remote Sens., v. 31, p. 448-453, 1996. 
MACHADO, W.; SANTELLI, R. E.; LOUREIRO, D. D.; OLIVEIRA, E. P.; BORGES, A. C.; MA, V. K.; LACERDA, L. D. Mercury accumulation in sediments along an eutrophication gradient in Guanabara Bay, Southeast Brazil. J .Braz. Chem. Soc., v. 19, p. 569$575,2008$.

MACKENZIE, F. T.; VER, L. M.; SABINE, C.; LANE, M.; LERMAN A. 1993. C, N, P, S global biogeochemical cycles and modeling of global change. In: WOLLAST R.; MACKENZIE, F.; CHOU, L. (Ed.). Interactions of $\mathbf{C}, \mathbf{N}, \mathbf{P}$ and $\mathbf{S}$ biogeochemical cycles and global change. Berlin:Springer Verlag. p. 2-61. 1993

MACKO, S. A.; ENGEL, M. H. PARKER, P. L. Early diagenesis of organic matter in sediments: assessment of mechanisms and preservation by the use of isotopic molecular approaches. In: ENGEL, M. H.; MACKO, S.A. (Ed.). Organic Geochemistry. New York: Plenum Press. p. 211-224. 1993.

MAHIQUES, M. M.; BÍCEGO, M. C.; SILVEIRA, I. M. O; SOUSA, S. H. M.; LOURENCCO, R. A.; FUKUMOTO, M. M. Modern sedimentation in the Cabo Frio upwelling system, Southeastern Brazilian shelf. An. Acad. Bras.Ciênc. v. 77, p. 535-548, 2005.

MAHIQUES, M. M.; TESSLER, M. G.; MARIA CIOTTI, A; DA SILVEIRA I. C. A.; SOUSA, S. H. D. M; FIGUEIRA, R. C. L.; TASSINARI, C. C .G.; FURTADO, V. V.; PASSOS, R. F. Hydrodynamically driven patterns of recent sedimentation in the shelf and upper slope off Southeast Brazil. Continent. Shelf Res., v. 24, p. 1685-1697, 2004.

MUZUKA, A. N. N.; HILLAIRE-MARCEL, C. Burial rates of organic matter along the eastern Canadian margin and stable isotope constraints on its origin and diagenetic evolution. Mar. Geol., v. 160, p. 251-270, 1999.

MCCALLEY, D. V.; COOKE, M.; NICKLESS, G. Effect of sewage treatment on faecal sterols. Water Res., v. 15, p. 1019-1025, 1981.

MCCALLISTER, S. L.; BAUER, J. E.; DUCKLOW, H. W.; CANUEL, E.A. Sources of estuarine dissolved and particulate organic matter: A multi-tracer approach. Org. Geochem., v. 37:, p. 454-468, 2006.

MCMANUS, G.; COSTAS, B.; DAM, H.; LOPES, R.; GAETA, S.; SUSINI, S; ROSETTA, C. Microzooplankton grazing of phytoplankton in a tropical upwelling region. Hydrobiologia, v. 575, p. 69-81, 2007.

MEAD, R.N.; GOÑI, M. A. Matrix protected organic matter in a river dominated margin: A possible mechanism to sequester terrestrial organic matter? Geochim. Cosmochim. Acta, v. 72, p. 2673-2686, 2008.

MEJANELLE, L.; LAUREILLARD J. Lipid biomarker record in surface sediments at three sites of contrasting productivity in the tropical North Eastern Atlantic. Mar. Chem., v. 108, p. 59-76, 2008.

MEYERS, P. A. Organic geochemical proxies of paleoceanographic, paleolimnologic, and paleoclimatic processes. Org. Geochem., v. 27, p. 213-250, 1997.

MOREIRA DA SILVA, P. C. A ressurgência de Cabo Frio (I). Bolm Inst. Pesq. Marinha, v. 78, p. 60-67, 1973.

NETO J.; GINGELE, F.; LEIPE, T.; BREHME， I. Spatial distribution of heavy metals in superficial sediments from Guanabara Bay: Rio de Janeiro, Brazil. Environ. Geol., v. 49, p. 1051-1063, 2006.
NISHIMURA, M. 5b-isomers of stanols and stanones as potential markers of sedimentary organic quality and depositional paleoenvironments. Geochim. Cosmochim. Acta, v. 46, p. 423-432, 1982.

ROSSI-WONGTSCHOWSKI, C. L.; MADUREIRA, L. A. S. O ambiente oceanográfico da plataforma continental e do talude da região sudeste-sul do Brasil. São Paulo: EDUSP. 466 p. 2006.

SALIOT, A; PARRISH, C. C.; SADOUNI, N.; BOULOUBASSI, I.; FILLAUX, J.; CAUWET G. Transport and fate of Danube Delta terrestrial organic matter in the Northwest Black Sea mixing zone. Mar. Chem., v. 79, p. 242-259, 2002.

SCHEFUSS E.; VERSTEEGH, G. J. M.; JANSEN, J. H. F.; SINNINGHE DAMSTE, J. S. Lipid biomarkers as major source and preservation indicators in SE Atlantic surface sediments. Deep Sea Res., I, Oceanogr. Res. Pap., n. 51, p. 1199-1228, 2004.

SCHMIDT, F.; HINRICHS, K-U.; ELVERT M. Sources, transport, and partitioning of organic matter at a highly dynamic continental margin. Mar. Chem., v. 118, p. 37-55, 2010.

SEIXAS, T. G.; MOREIRA, I.; KEHRIG, H. D. A.; MALM, O. Distribution of selenium in marine organisms from Guanabara Bay/ RJ. Quim. Nova, v. 30, p. 554-559, 2007.

SILVEIRA, I. M. O.; SCHMIDT, A. C. K.; CAMPOS, E. J. D.; GODOY, S. S. IKEDA, Y. A Corrente do Brasil ao largo da costa brasileira. Rev. Bras. Oceanogr., v. 48, p. 171-183, 2000.

SOARES-GOMES A.; ABREU, C. M. R. C.; ABSHER, T. M.; FIGUEIREDO, A. G. Abiotic features and the abundance of macrozoobenthos of continental margin sediments of East Brazil. Arch. Fish. mar. Res., v. 47, p. 321-334, 1999.

SUMIDA, P. Y. G.; YOSHINAGA, M. Y.; CIOTTI, A. M. GAETA, S. A. 2005. Benthic response to upwelling events of the SE Brazilian coast. Mar. Ecol. Prog. Ser., v. 291 , p. $35-42,2005$

TESI, T.; MISEROCCHI, S.; GONI, M. A.; LANGONE,L,.; BOLDRIN, A.; TURCHETTO, M. Organic matter origin and distribution in suspended particulate materials and surficial sediments from the western Adriatic Sea (Italy). Estuar. coast Shelf Sci., v. 73, p. 431-446, 2007.

VALENTIN, J. L. Analyse des paramétres hydrobiologiques dans la remotée de Cabo Frio (Brésil). Mar Biol., v. 82, p. 259-276, 1984

VALENTIN, J. L.; ANDRÉ, D .L.; JACOB, S. A.; Hydrobiology in the Cabo Frio (Brazil) upwelling : two dimensional structure and variability during a wind cycle. Continent. Shelf Res., v. 7, p. 77-88, 1987.

VALENTIN, J. L.; KEMPF, M. Some characteristics of the Cabo Frio upwelling. Coast. Upwelling Ecosyst. Analysis Newsl., v. 6, p. 18-19, 1977.

VALENTIN, J. L.; SILVA, N. M. L.; MONTEIRO-RIBAS, W. M.; MUREB, M. A.; BASTOS, C. T. B. T.; TENENBAUM, D. R.; ANDRÉ, D. L.; JACOB, S. A.; PESSOTI, E. Le plancton dans l'upwelling de Cabo Frio (Brésil): microrépartition spatio-temporelle à une station fixe. Annls Inst. Océanogr., Paris, , v. 62, p. 117-135, 1986.

VER, L. M. B.; MACKENZIE, F. T.; LERMAN, A. Carbon cycle in the coastal zone: effects of global pertubations 
and change in the past three centuries. Chem. Geol., v. 159 , p. 283-304, 1999.

VOLKMAN, J. K. A review of sterol markers for marine and terrigenous organic matter. Org. Geochem.,v. 9, p. 83-99, 1986

VOLKMAN J. K. Lipid markers for marine organic matter. In: VOLKMAN, J.K. (Ed.). Handbook of Environmental Chemistry, v. 2: Reactions and Processes $2(\mathrm{~N})$. Berlin:Springer Verlag. p. 27-70. 2006.

VOLKMAN, J. K.; BARRET, S. M.; BLACKBURN, S. I.; MANSOUR, M. P.; SIKES, E. L.; GELIN, F. Microalgal biomarkers: a review of recent research developments. Org. Geochem., v. 29, p. 1163-1179, 1998.

VONK, J. E.; VAN DONGEN, B. E.; GUSTAFSSON, Ö. Lipid biomarker investigation of the origin and diagenetic state of sub-arctic terrestrial organic matter presently exported into the northern Bothnian Bay. Mar. Chem., v. 112, p. 1-10, 2008.

WAGENER, A. L. R. Burial of organic carbon in estuarine zones - estimates for Guanabara Bay, Rio de Janeiro. Quim. Nova, v. 18, p. 534-535, 1995.

WAKEHAM, S. G.; CANUEL, E. A. Degradation and preservation of organic matter in sediments. In: VOLKMAN, J. K. (Ed.). Handbook of Environmental Chemistry, v. 2: Reactions and Processes 2 (N). Berlin:Springer Verlag. p. 295-321. 2006.

WAKEHAM, S. G.; FARRINGTON, J. W.; GAGOSIAN, R. B. Variability in lipid flux and composition of particulate matter in the Peru upwelling region. Org. Geochem.,v. 6, 203-215, 1984.

WAKEHAM, S. G.; PETERSON, M. L.; HEDGES, J. I.; LEE, C. Lipid biomarker fluxes in the Arabian Sea, with a comparison to the equatorial Pacific Ocean. Deep Sea Res., II, Top Stud Oceanogr., v. 49, p. 2265-2301, 2002.
WATERSON, E. J.; CANUEL, E. A. Sources of sedimentary organic matter in the Mississippi River and adjacent Gulf of Mexico as revealed by lipid biomarker and $\mathrm{d}^{13} \mathrm{C}_{\mathrm{TOC}}$ analyses. Org. Geochem., v. 39, p. 422439, 2008.

XU, Y.; HOLMES, C. W.; JAFFE, R. Paleoenvironmental assessment of recent environmental changes in Florida Bay, USA: A biomarker based study. Estuar. coast. Shelf Sci., v. 73, p. 201-210, 2007.

YOSHINAGA, M. Y.; SUMIDA, P. Y. G.; WAKEHAM,. S. G. Lipid biomarkers in surface sediments from an unusual coastal upwelling area from the SW Atlantic Ocean. Org. Geochem., v. 39, p. 1385-1399, 2008.

YUNKER, M. B.; BELICKA, L. L.; HARVEY, H. R.; MACDONALD, R. W. Tracing the inputs and fate of marine and terrigenous organic matter in Arctic Ocean sediments: A multivariate analysis of lipid biomarkers. Deep Sea Res., II, Top Stud. Oceanogr., v. 52, p. 34783508, 2005.

ZIMMERMAN, A. R.; CANUEL, E. A. A geochemical record of eutrophication and anoxia in Chesapeake Bay sediments: anthropogenic influence on organic matter composition. Mar .Chem., v. 69, p. 117-137, 2000.

(Manuscript received 19 August 2011; revised 18 November 2011; accepted 12 January 2012) 